\title{
The Empirical Study on Risk Information Disclosure of Banking Industry and Business Performance
}

\author{
Sun-Lei Yang* \\ School of Accounting, Wuhan Textile University, Wuhan, \\ Hubei, China \\ Email:50495815@qq.com \\ *Corresponding author \\ Zi-Xuan Zhou \\ School of Accounting, Wuhan Textile University, Wuhan, \\ Hubei, China \\ Email:2874535517@qq.com,
}

\author{
Bi-Xiao Sun \\ School of Accounting, Wuhan Textile University, Wuhan, \\ Hubei, China \\ Email:416952050@qq.com \\ Xiong-Fei Liu \\ School of Accounting, Wuhan Textile University, Wuhan, \\ Hubei, China \\ Email: 228327730@qq.com
}

\begin{abstract}
This paper empirically examined the influence of risk information disclosure on business performance with method of regression analysis, based on the data from 8 listed banking from 2011 to 2015 . The conclusion shows that the higher the level of risk information disclosure is, the better the future business performance is, that is to say, improving baking's risk information disclosure can benefit the improvement of business performance. The innovation of this paper is to study risk information disclosure of economic consequences in banking industry.
\end{abstract}

Keywords- Banking Industry, Risk Information Disclosure, Business Performance.

\section{INTRODUCTION}

As an important part of financial system, the nature of business determines that banking industry has high-sensitive and high-risk characteristics. The mature market economy in developed countries has been attaching great importance to risk information disclosure in banking industry. Since our country China joins the WTO, banking industry is required to disclose relevant risk information in order to achieve the aim of safe, stable and efficient operation. People's Bank of China published Interim measures for the commercial bank information disclosure on May 15, 2002, from which risk information disclosure is regulated specially, meaning risks in commercial bank will have formal and standardized information disclosure. In 2007, China Securities Regulatory Commission publishes the document of commercial bank information disclosure. In this background, can the sufficient and transparent risk information disclosure in commercial bank help the banking to gain better economic performance? Based on the data from 8 listed banking from 2011 to 2015 , the article empirically testes the influence of risk information disclosure on banking business performance. The research result shows that the higher the level of risk information disclosure is, the higher return on assets is.

\section{LITERATURE REVIEW AND RESEARCH HYPOTHESIS}

The overseas research on banking risk information disclosure starts early. Chari.V. and R Jagannathan (1996) research the validity limit risk of market discipline and observability of financial safety net, through investigating 729 banks in 23 countries. And they conduct empirical analysis on relevant banking risk hypotheses, verifying the risk information disclosure indeed can reduce the risk of bankrupt [1]. However, the domestic research on risk information disclosure starts relatively late and bases on standard research. Li-na Wang, Wei-dong Zhu (2011) build a model based on two-duple information processing method to conduct appraisal and fulfill the quantitative analysis on banking risk information disclosure[2]. Xiao-ling Zheng makes penetrating analysis on listed banking risk information disclosure, mainly by analyzing some system about risk disclosure to build listed banking risk information disclosure index, then provides some specific measures to improve risk information disclosure level [3]. A. Berger and DeYoung (1997) think information disclosure can strength the market force weaken the risk taking and improve banking operating performance [4]. According to these literatures, following hypothesizes can be inferred.

Hypothesis: When other condition remains the same, higher level of risk disclosure can bring about better financial performance.

\section{RESEARCH DESIGN}

\section{A. Data Resource}

The paper manually collects 5 -year annual report on 8 listed banks from 2011 to 2015 in cninfo.com and store data on risk information disclosure from these reports. The 8 banks are Bank of China Limited, China Merchants Bank Co, Ping An Bank Co, Agricultural Bank of China Ltd, Bank of Communications Company Limited, China Construction Bank Co, Everbright bank co., Ltd. The data 
process and analysis use Excel 2010 and STATA11 statistical software. Other financial data come from CSMAR data.

\section{B. Variable Choice}

[1] Explanatory Variable.

Explanatory variable is risk information disclosure index (RID). Combing the requirement of commercial bank information disclosure and listed banks information disclosure from regulation sector, the article builds RID. The article refers to the risk assessment about banking information disclosure from the articles, such as Xiao-ling Zheng (2011) and build listed banks' risk management information disclosure. The specific ranking category and project have 7 items. The first one is assets, including the key feature and circumstance of capital instrument, especially the complex innovation and hybrid capital instrument; tier one capital; tier 2 and 3 capital; other deductions of capital; qualified capital. The second one is capital adequacy ratio, including the detailed description of the capital adequacy ratio assessment method. The content of description is based on the current and future development of banks; the capital requirement of credit risks; the capital requirement of equity investment risk in internal rating based approach; the capital requirement of market risk; the capital requirement of operating risk; the total capital adequacy ratio and tier one capital adequacy ratio. The third one is credit risk, including the bank credit risk; the illustration of bank fund management and method; the description of relevant credit risk system. For those banks which don't take certain ranking methods, different description should be conducted on different asset mix risk nature. The description would take three methods as followed: the standard IRB approach, primary IRB approach and senior IRB approach. And the amount, place and object condition of credit risk should be included in credit risk. All asset mix should be classified on residual contract term. Other items, such as total penalty clause, risk information loss concentrated on certain area, and the adjustment of loan loss reserves. The forth one is the market risk. It includes the illustration of market risk nature, category and risk level, and reflection of market to price, which has the stock price change in stock market to the overall value on listed bank and its profit association in a certain week time, and asset mix covered by standard IRB approach. Fifthly, operating risk. It includes the whole circumstance, the assessment of operating process method, the whole consideration description taken into when conducting risk measurement and capital requirement description when taking senior IRB approach in using risk operation. The sixth one is liquid risk. It includes analyzing the deadline and structure matching circumstance on asset and liability, analyzing of all kind of circumstance leading to liquid change, describing the detailed liquid management, and listing relevant index reflecting liquidity. The seventh one is other risk. It contains other risk factors descriptions on negative impact on banks, potential risk in derivative financial instrument and hedging instrument, the risk measurement model and its method of derivative financial instrument.

The score and its item of each risk information disclosure don't handle on weight. For relevant item disclosed in the listed bank annual report, if it's detailed described, 2 score is given.1score is given to general described and 0 to none description. In the ranking system, the whole score of risk information disclosure item is 66 and its content is divided into 7 categories, 33 small items. The article uses the score sum of all listed bank risk information disclosure from 2011 to 2015 to represent the risk information disclosure index, which is used to reflect its risk information disclosure level.

\section{Explained Variable.}

The explained variable is business performance, presenting with ROA.

\section{Control Variable.}

Control variable includes the firm-specific factor, mainly using the firm size, the number of independent directors to weight. Specific variable definition is showed in Table 1.

TABLE.I VARIABLE DEFINITION TABLE.

\begin{tabular}{|c|c|}
\hline variable & variable definition \\
\hline ROA & ROA= net profit/total assets \\
\hline RID & $\begin{array}{r}\text { Risk information disclosure index is given according to the disclosure of } 66 \text { items. } 2 \text { score is given for detailed } \\
\text { described.1score is given to general described and } 0 \text { to none description. Total is } 66 \text { scores }\end{array}$ \\
\hline Size & Size means the firm scale, using the total assets logs at end of term to measure. \\
\hline DDR & $\begin{array}{c}\text { DDR presents the company governance structure, using the number of independent directors divide the total board number to } \\
\text { weight }\end{array}$ \\
\hline
\end{tabular}




\section{E. Model Building.}

Taking the endogenous problem into consideration, the explanatory variable and explained variable in this article use first-lagged data. The model is set as follow:
$\mathrm{ROA}_{\mathrm{t}}=\beta_{0}+\beta_{1} \mathrm{RID}_{\mathrm{t}-1}+\beta_{2} \operatorname{Size}_{\mathrm{t}-1}+\beta_{3} \mathrm{DDR}_{\mathrm{t}-1}+\varepsilon$

(1)

\section{THE EMPIRICAL RESULT ANALYSIS}

\section{A. Descriptive Analysis}

TABLE.II SAMPLE DESCRIPTIVE ANALYSIS TABLE.

\begin{tabular}{|l|l|l|l|l|l|}
\hline Variable & Obs & Mean & Std. Dev. & Min & Max \\
\hline RID & 40 & 25.6 & 12.92543 & 9 & 50 \\
\hline size & 40 & 29.43327 & 1.175203 & 26.4143 & 30.73155 \\
\hline DDR & 40 & 0.361106 & 0.041876 & 0.25 & 0.5 \\
\hline ROA & 40 & 0.014407 & 0.008484 & 0.008721 & 0.041341 \\
\hline
\end{tabular}

From Table 2, the descriptive analysis result shows that the mean value of RID is 25.6 and the variance is 12.92543, meaning that overall listed bank risk information disclosure in China isn't high enough. The mean of ROA is 0.0144 , meaning the average reward of China listed banking industry is relatively low.

\section{B. Correlation Analysis}

Main variables correlation coefficient analyses are shown in Table 3

TABLE.III CORRELATION COEFFICIENT TABLE

\begin{tabular}{|l|r|r|r|l|}
\hline & \multicolumn{1}{|l|}{ ROA } & Size & DDR \\
\hline ROA & 1 & & & \\
\hline RID & -0.2244 & 1 & & \\
\hline & 0.2169 & & & \\
\hline size & $-0.6341^{* * *}$ & 0.6782 & 1 & \\
\hline & 0.0001 & 0 & & \\
\hline DDR & 0.0996 & 0.1827 & 0.2418 & \\
\hline & 0.5875 & 0.3169 & 0.1824 & \\
\hline
\end{tabular}

Table 3 shows that correlation coefficient between risk information disclosure and return on assets is 0.2244 , that is, risk information disclosure is negatively correlated with return on assets .correlation coefficient preliminary verify hypothesis 1 .

\section{Regression Analysis}

Regression analysis tests the relationship of risk information disclosure and business performance, showing in the Table 4.

TABLE.IV REGRESSION ANALYSIS TABLE.

\begin{tabular}{|l|l|l|}
\hline VARIABLES & coefficient & T \\
\hline RID & $0.000234^{* *}$ & -0.000109 \\
\hline size & $-0.00636^{* * *}$ & -0.00118 \\
\hline DDR & $0.0467^{*}$ & -0.0235 \\
\hline Constant & $0.178^{* * *}$ & -0.0324 \\
\hline Observations & 32 & \\
\hline R-squared & 0.545 & \\
\hline
\end{tabular}

$$
* * * \mathrm{p}<0.01, * * \mathrm{p}<0.05, * \mathrm{p}<0.1
$$

From Table 4, the regression coefficient of ROA and risk information disclosure is 0.000234 , representing RID and ROA are positively correlated. And when $\mathrm{p}<0.05$, the result is significant, meaning RID can affect ROA 
significantly. The higher RID is, ROA is higher also. The hypothesis 1 proves right. The regression coefficient of ROA and company size is -0.00636 , representing ROA and company size are negatively. While when $\mathrm{p}<0.01$, the result is significant, meaning the larger the company size is, ROA is smaller. The regression coefficient of ROA and DDR is 0.0467 , representing they are positively correlated. And when $\mathrm{p}<0.1$, the result is significant, meaning when DDR is high, ROA is high as well.

\section{V.CONCLUSION}

This paper uses 8 China listed companies as samples, and analyses the influence of risk information disclosure on business performance, and the conclusion shows: the higher risk information disclosure of bank is, ROA is higher. Meanwhile, company size and ROA are negatively, DDR and ROA are positively correlated.

\section{REFERENCE}

[1] Chari.V. R Jagannathan, Banking Panies, Information and Rational, 1996, 2: 68-71.

[2] Wang Lina, Zhu Weidong. Risk disclosure evaluation of commercial bank, Journal of Hefei University of Technology (Natural Science), 2011, 34 (7):1084-1086.

[3] Zheng Xiaoling, The research on China listed bank risk information disclosure, Economic \& Trade Update, 2008,114 (6):203-204

[4] Berger, A., \& DeYoung, R. . Problem loans and cost efficiency in commercial banks. Journal of Banking \& Finance, 1997,21:849-870. 